\title{
PENERAPAN ALGORITMA WINNOWING UNTUK MENDETEKSI KEMIRIPAN PADA KARYA TULIS MAHASISWA
}

\author{
Ilham $^{1}$, Pasnur $^{2}$ \\ Teknik Informatika ${ }^{1}$, Sistem Informasi ${ }^{2}$, STMIK AKBA \\ ilham_eng@yahoo.com¹,pasnur@akba.ac.id ${ }^{2}$
}

\begin{abstract}
ABSTRAK
Keberadaan Teknologi Informasi (TI) yang sedemikian berkembang, menyebabkan kegiatan plagiarism semakin berkembang pula. Hal ini cukup banyak dilakukan di kalangan akademisi di perguruan tinggi, yang dituntut untuk memenuhi kegiatan tri dharma khususnya kegiatan penelitian. Cikal bakal akademisi adalah mahasiswa-mahasiswa yang juga dituntut untuk melakukan penelitian juga. Dalam penelitian ini, dilakukan penerapan algoritma winnowing untuk mendeteksi kemiripan dokumen karya tulis mahasiswa Beberapa skenario pengujian dilakukan dengan mengubah nilai parameter gram dan window untuk mendapatkan nilai optimal. Nilai optimal ini akan diterapkan pada aplikasi yang akan dibangun.
\end{abstract}

Kata Kunci:Algoritma Winnowing, kemiripan dokumen.

\begin{abstract}
The existence of Information Technology (IT) is so developing, causing the activity of plagiarism growing also. This is pretty much done among academics in universities, which are required to fulfill the activities of tri dharma especially research activities. The embryo of academics are students who are also required to conduct research as well. In this research, the application of winnowing algorithm to detect the resemblance of student paper documents. Some test scenarios are done by changing the value of gram and window parameters to get optimal value. This optimal value will be applied to the application to be built.
\end{abstract}

Keywords:Winnowing Algorithm, file similarity.

\section{Pendahuluan}

Teknologi informasi (TI) telah menjadi kebutuhan mendasar pada setiap perguruan tinggi terutama dalam kegiatan akademik. Proses perkuliahan sebagai inti dari kegiatan akademik sangat mengandalkan TI dalam interaksi antara dosen dan mahasiswa. Salah satunya adalah cara mengumpulkan tugas. Dosen seringkali meminta mahasiswa mengumpulkan tugas dalam bentuk dokumen elektronik. Hal ini seringkali dimanfaatkan oleh mahasiswa dengan mengumpulkan salinan dokumen milik mahasiswa lainnya.

Kesamaan dokumen yang dikumpulkan oleh mahasiswa, membuat dosen tidak dapat bekerja secara efektif dan efisien karena kemungkinan untuk memeriksa tugas yang sama atau mirip adalah sangat besar. Sedangkan dampaknya terhadap mahasiswa adalah tumbuhnya sikap malas dan bermasa bodoh dalam membuat tugas mata kuliah. Hal ini juga dapat berakibat pada kurangnya keterampilan/keahlian dalam bidang tertentu.

Berdasarkan beberapa kondisi yang telah disebutkan sebelumnya, maka perlu dibangun aplikasi pengunggah dokumen yang mampu mendeteksi kesamaan teks pada dokumen karya tulis mahasiswa satu dengan yang lainnya. Dalam rangka membangun aplikasi ini, diperlukan algoritma yang mampu mendeteksi keberadaan kalimat yang sama dari dokumen yang dibandingkan.

Dari beberapa studi literatur yang berasal dari penelitian-penelitian dengan topik sejenis, memaparkan bahwa algoritma pendeteksi penjiplakan harus memenuhi tiga syarat, yaitu whitespace insensitivity, noise suppression, dan position independence [Kusmawan, 2010]. 
Algoritma Winnowing memenuhi ketiga hal tersebut. Algoritma Winnowing membuat fingerprint dari sebuah dokumen dengan melalui ketiga proses yang disyaratkan [Diana, 2011].

Pada penelitian ini, dilakukan beberapa skenario untuk menguji kemampuan Algoritma Winnowing. Skenario pengujian akan berbeda dalam hal nilai parameter. Dari pengujian tersebut, diharapkan diperoleh nilai optimal parameter yang akan diterapkan pada aplikasi yang akan dibangun.

\section{Tinjauan Pustaka}

Penjiplakan atau plagiat adalah perbuatan sengaja atau tidak sengaja dalam memperoleh atau mencoba memperoleh kredit atau nilai untuk suatu karya ilmiah, dengan mengutip sebagian atau seluruh karya dan atau karya ilmiah pihak lain yang diakui sebagai karya ilmiahnya, tanpa menyatakan sumber secara tepat dan memadai [Permen 17].

Deteksi penjiplakan dokumen dapat dilakukan dengan menerapkan metode atau algoritma yang sesuai, yaitu algoritma yang memenuhi tiga hal berikut ini [3]: a) Whitespace Insensitivity, yaitu dalam pencocokan dokumen teks, tidak terpengaruh oleh spasi, jenis huruf (kapital atau normal), tanda baca, dan sebagainya; b) Noise Suppression, yaitu setiap penemuan kecocokan dengan panjang kata atau rangkaian kata (string) yang kecil akan diabaikan seperti kata 'dan'; serta c) Position Independence, yaitu penemuan kecocokan yang tidak bergantung pada posisi string. Berdasarkan tiga syarat tersebut, maka dalam penelitian ini akan digunakan Algoritma Winnowing untuk mendeteksi penjiplakan.

Algoritma Winnowing adalah algoritma yang digunakan untuk membuat fingerprint dari sebuah dokumen [3]. Algoritma winnowing mengubah dokumen teks menjadi sekumpulan nilai hash yang disebut sebagai fingerprint. Proses untuk menghasilkan fingerprint dari sebuah dokumen adalah sebagai berikut:

a.Membuang karakter-karakter yang tidak relevan seperti spasi, tanda baca maupun artikel atau kata yang tidak penting, misalnya kata sambung. Langkah ini sesuai dengan syarat algoritma pendeteksi penjiplakan yaitu whitespace insensitivity dan noise suppression.

b.Membentuk rangkaian n-gram dari teks. Semisal ditentukan $\mathrm{n}=6$, maka akan dihasilkan sekumpulan gram atau string yang berukuran 6 .

c. Melakukan fungsi hash untuk setiap gram. Persamaan (1) adalah perhitungan fungsi hash dari algoritma winnowing [4].

$$
\begin{gathered}
H_{\left(c_{1} \ldots c_{k}\right)}=c_{1} * b^{k-1}+c_{2} * b^{k-2}+\cdots \\
+c_{k-1} * b^{k}+c_{k} \\
H_{\left(c_{2} \ldots c_{k+1}\right)}=\left(\begin{array}{c}
\left.H_{\left(c_{1} \ldots c_{k}\right)}-c_{1} * b^{k-1}\right) * b \\
+c_{k+1} \ldots(1)
\end{array}\right.
\end{gathered}
$$

$\mathrm{H}$ adalah nilai hash, $\mathrm{c}$ adalah karakter pada gram, b adalah bilangan basis, dan $\mathrm{k}$ adalah jumlah karakter gram.

d.Membuat himpunan-himpunan yang disebut window yang terdiri dari i nilai hash. Jika $\mathrm{i}=6$, maka di dalam satu window terdapat 6 nilai hash.

e.Memilih fingerprint dari hasil hashing dengan pembagian hasil hash berdasarkan satu nilai window $\mathrm{w}$, dan kemudian dipilih nilai hash terkecil dari setiap window tersebut.

Langkah $\mathrm{b}-\mathrm{e}$, berkaitan dengan syarat Position Independence. Dengan membentuk fingerprint dari sebuah dokumen teks, maka dapat dilakukan komparasi dengan fingerprint dokumen lainnya tanpa menghiraukan posisi dari fingerprint tersebut.

\section{Metode Penelitian}

Penerapan dari algoritma Winnowing membutuhkan masukan berupa dokumen teks yang kemudian akan menghasilkan luaran berupa fingerprint dari dokumen tersebut.Seluruh proses untuk menghasilkan fingerprint dokumen ditunjukkan pada Gambar 1. 


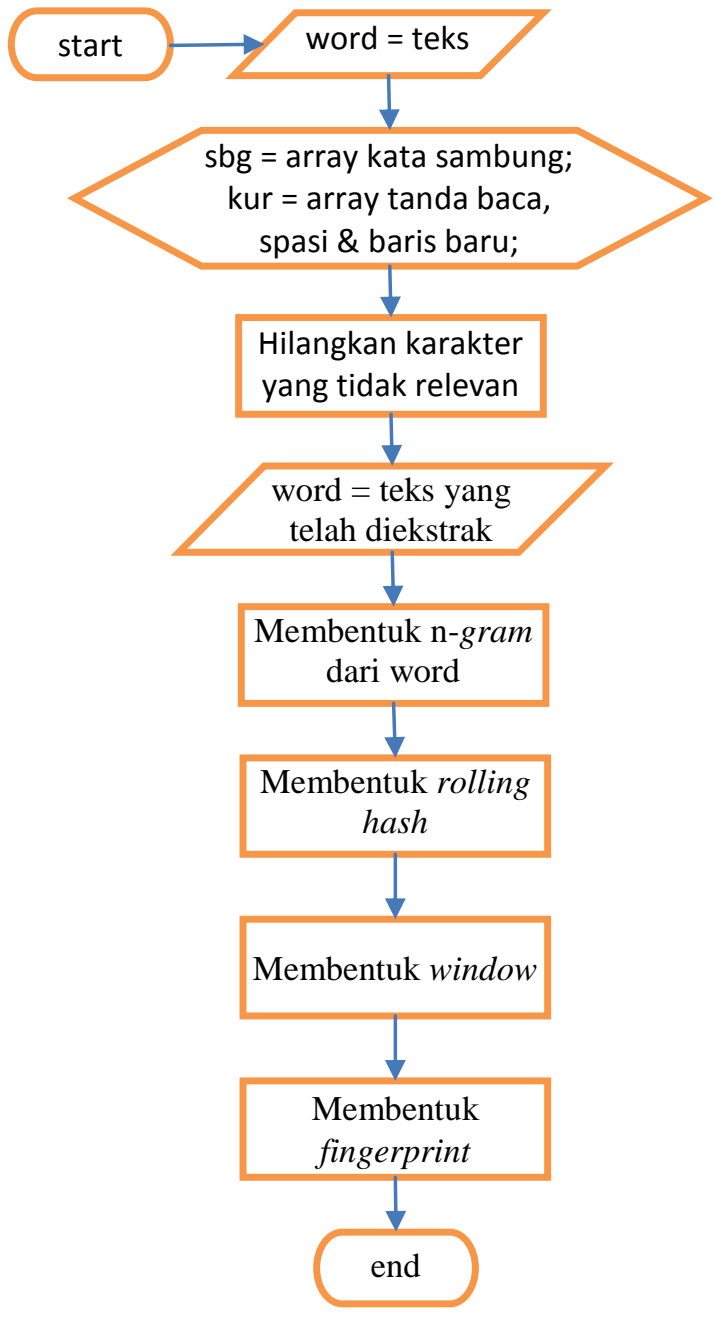

Gambar 1. Diagram alir pembentukan fingerprint dokumen teks

Hasil fingerprint dokumen kemudian akan dibandingkan dengan fingerprint dari dokumen lainnya. Skenario pengujian akan dilakukan berdasarkan nilai parameter gram, window, dan basis bilangan prima terhadap 5 dukumen tugas mahasiswa pada mata kuliah Metode Penelitian di STMIK Akba Makassar seperti yang tercantum pada Tabel 1 berikut ini.

\begin{tabular}{cc}
\hline Dokumen & Nama Mahasiswa \\
\hline A & Abdul Rahmat Susilo \\
B & Fahmi Idrus \\
C & Topan Leoni \\
D & Andi Hasriyati \\
E & Fahri Nuryasin \\
\hline
\end{tabular}

Pengujian pada penelitian ini terdiri atas dua skenario berdasarkan nilai parameter gram, window, dan basis. Skenario pertama menggunakan nilai ukuran gram adalah 5, window $=4$, dan bilangan basis $=2$. Sedangkan skenario kedua menggunakan ukuran gram $=8$, window $=$ 6, dan bilangan basis $=23$.

\section{Hasil dan Pembahasan}

Hasil dari penelitian ini adalah berupa library pemrograman Algoritma Winnowing dalam Bahasa Pemrograman PHP dan Aplikasi berbasis web sederhana yang menerapkan library tersebut. Gambar 2 berikut iniadalah halaman awal aplikasi web.

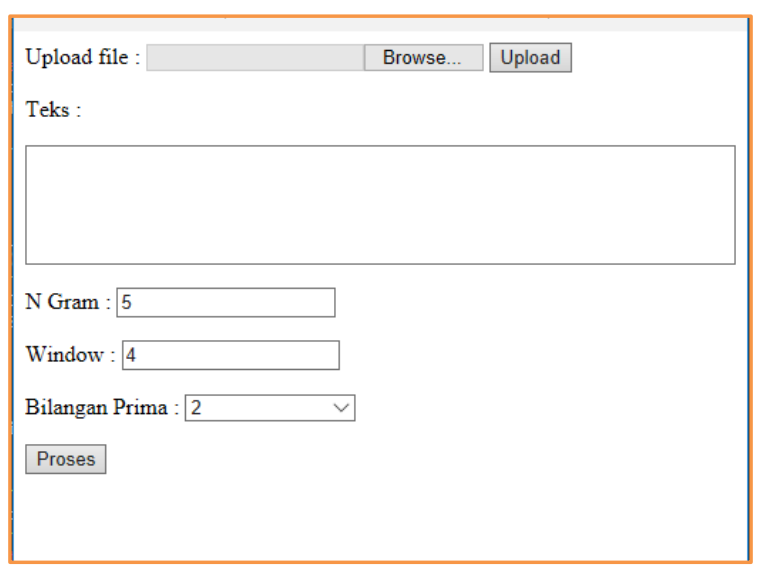

Gambar 2. Halaman awal aplikasi

Di halaman awal tersebut, dapat diunggah sebuah dokumen dengan menggunakan fiur Upload file. Jika tombol Upload ditekan, maka dokumen yang diunggah secara otomatis akan muncul dalam area teks, seperti yang ditunjukkan pada Gambar 3. 


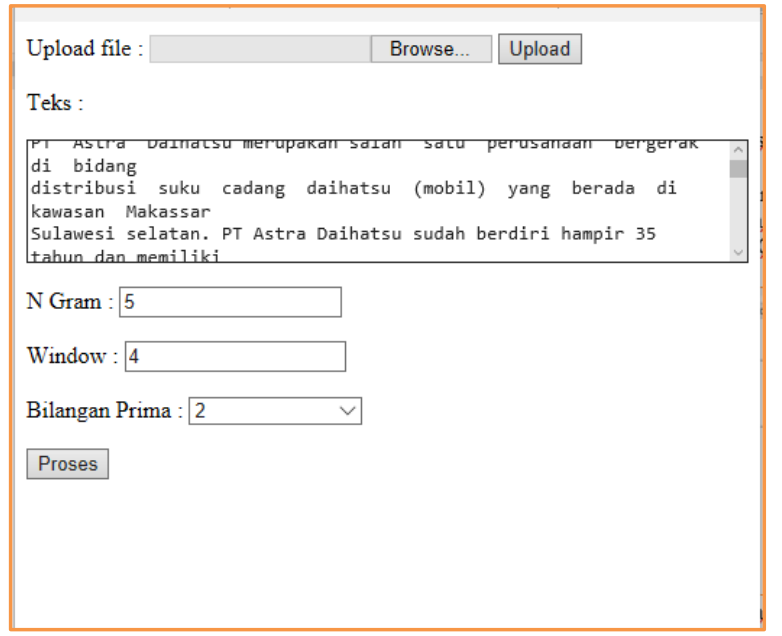

Gambar 3. Tampilan ketika telah mengunggah dokumen

Pada halaman awal, juga terdapat bagian untuk memasukkan nilai gram, window, dan bilangan basis. Jika tombol Proses ditekan,tombol ini akan memanggil library algoritma Winnowing untuk membentuk fingerprint dokumen. Hasil dari proses ditunjukkan pada Gambar 4.

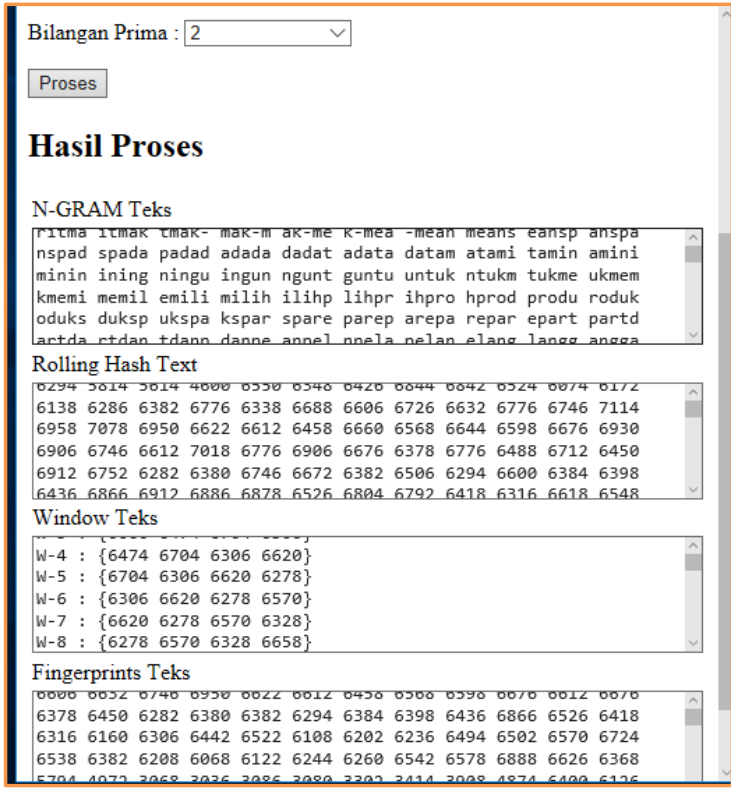

Gambar 4. Tampilan proses pembentukan fingerprint dokumen teks

Hasil ini kemudian diuji dengan menggunakan 5 dokumen yang telah disebutkan pada Tabel 1. Untuk ukuran gram $=5$, window $=4$, dan bilangan basis $=2$, dihasilkan fingerprint sesuai dengan yangditunjukkan pada Tabel 2. Sedangkan
Tabel 3 menunjukkan hasil pembentukan fingerprint dengan nilai gram $=8$, window $=6$, dan basis $=23$.

Tabel 2. Hasil pembentukan fingerprint dengan gram $=5$, window $=4$, basis $=2$

\begin{tabular}{cc}
\hline Dokumen & $\begin{array}{c}\text { Jumlah fingerprint yang } \\
\text { terbentuk }\end{array}$ \\
\hline A & 7199 \\
B & 15694 \\
C & 18175 \\
D & 10823 \\
E & 10824 \\
\hline
\end{tabular}

Tabel 3. Hasil pembentukan fingerprint dengan gram $=8$, window $=6$, basis $=23$

\begin{tabular}{cc}
\hline Dokumen & $\begin{array}{c}\text { Jumlah fingerprint yang } \\
\text { terbentuk }\end{array}$ \\
\hline A & 4561 \\
B & 9932 \\
C & 11367 \\
D & 6926 \\
E & 6928 \\
\hline
\end{tabular}

Dari hasil pembentukan fingerprint, kemudian dibandingkan dengan fingerprint dari dokumen lainnya. Tabel 4 berikut menunjukkan tingkat kemiripan antar dokumen berdasarkan gram $=5$, window $=4$, dan basis $=2$.

Tabel 4. Tingkat kemiripan antar dokumen dengan parameter gram $=5$, window $=4$, basis $=2$

\begin{tabular}{cc}
\hline $\begin{array}{c}\text { Dokumen } \\
\text { yang } \\
\text { dibandingkan }\end{array}$ & $\begin{array}{c}\text { Tingkat Kemiripan } \\
(\%)\end{array}$ \\
\hline A-B & 44.21 \\
A-C & 38.39 \\
A-D & 62.32 \\
A-E & 62.33 \\
B-C & 82.99 \\
B-D & 130.82 \\
B-E & 130.81 \\
C-D & 140.49 \\
C-E & 140.48 \\
D-E & 99.86 \\
\hline
\end{tabular}

Dari hasil yang diperoleh pada Tabel 4, tampak bahwa tingkat kemiripan antar dua 
dokumen adalah cukup besar. Bahkan terdapat tingkat kemiripan di atas $100 \%$. Hal ini dapat disebabkan oleh nilai parameter gramdan basis yang ditentukan terlalu kecil sehingga memungkinkan banyak fingerprint yang sama pada kedua dokumen. Tingkat kemiripan di atas 100\% menunjukkan bahwa fingerprint yang diperoleh dari nilai gram dan basis yang kecil, tidak dapat dibandingkan karena kemungkinan untuk memperoleh fingerprint yang sama sangat tinggi.

Kemudian, dilakukan pula perbandingan antar fingerprint dari dua dokumen dengan menggunakan nilai parameter yang berbeda, yaitu gram $=8$, window $=6$, dan basis=23. Hasilnya ditunjukkan pada Tabel 5 berikut ini.

Tabel 5. Tingkat kemiripan antar dokumen dengan parameter gram $=8$, window $=6$, basis $=23$

\begin{tabular}{cc}
\hline $\begin{array}{c}\text { Dokumen } \\
\text { yang } \\
\text { dibandingkan }\end{array}$ & $\begin{array}{c}\text { Tingkat Kemiripan } \\
(\%)\end{array}$ \\
\hline A-B & 7.75 \\
A-C & 5.55 \\
A-D & 7.27 \\
A-E & 7.31 \\
B-C & 9.05 \\
B-D & 8.79 \\
B-E & 8.80 \\
C-D & 8.82 \\
C-E & 8.81 \\
D-E & 99.57 \\
\hline
\end{tabular}

Dari hasil yang diperoleh pada Tabel 5 menunjukkan nilai tingkat kemiripan yang normal. Dokumen A tidak menunjukkan kemiripan dengan dokumen lainnya. Begitu pula dengan dokumen B dan C. Namun, tidak demikian halnya pada dokumen D dan E. Hasil perbandingan fingerprint antar kedua dokumen tersebut menunjukkan tingkat kemiripan yang sangat besar yaitu $99.57 \%$. Jika merujuk pada Tabel 4, hasil perbandingan antar kedua dokumen juga menunjukkan tingkat kemiripan yang hampir sama yaitu
99.86\%. Begitu pula jika merujuk pada Tabel 2 dan 3 yang menunjukkan bahwa jumlah fingerprint yang dihasilkan dari kedua dokumen tersebut hampir sama. Pada Tabel 2, jumlah fingerprint yang dibentuk dari dokumen D adalah sebanyak 10823 fingerprint. Hampir sama dengan yang dihasilkan dari dokumen $\mathrm{E}$ yaitu 10824 fingerprint. Begitu pula pada Tabel 3 yang menunjukkan hal yang sama yaitu dokumen D sebanyak 6926 fingerprint dan dokumen E sebanyak 6928 fingerprint. Dari uraian di atas menunjukkan bahwa dokumen D dan E dapat dikatakan mirip satu sama lain.

\section{Kesimpulan dan Saran}

Adapun kesimpulan yang dapat ditarik dari hasil yang diperoleh adalah sebagai berikut.

Nilai parameter gram dan basis yang kecil tidak dapat digunakan untuk membentuk fingerprint karena dapat diperoleh tingkat kemiripan di atas $100 \%$.

Aplikasi pengunggah dokumen yang ingin dihasilkan berikutnya, dapat menggunakan nilai parameter gram $=8$, window $=6$, dan basis $=23$.

Algoritma Winnowing terbukti dapat mendeteksi kemiripan antar dua dokumen dengan membandingkan fingerprint yang dihasilkan dari dua dokumen tersebut.

Adapun saran untuk pengembangan penelitian adalah menambahkan skenario pengujian dengan nilai parameter yang berbeda sehingga dapat diperoleh hasil optimal.

\section{Daftar Pustaka}

[1] Azhar F, dkk, Aplikasi Pendeteksi Kemiripan pada Dokumen Teks Menggunakan Algoritma Nazief \& Adriani dan Metode Cosine Similarity, 2014

[2] Diana P, dkk, Deteksi Keberadaan Kalimat Sama sebagai Indikasi Penjiplakan dengan Algoritma Hashing Berbasis N-Gram, 2011. 
[3] Kamus Besar Bahasa Indonesia, (http://kbbi.web.id), diakses tanggal 26 mei 2016.

[4] Peraturan Menteri Pendidikan RI Nomor 17 Tahun 2010, Tentang Pencegahan dan Penanggulangan Plagiat di Perguruan Tinggi.

[5] Putu Y. K., dkk, Aplikasi Pendeteksi Penjiplakan pada File Teks dengan Algoritma Winnowing, 2010. 